\title{
BUILDING CHILDREN CHARACTER THROUGH MORAL VALUES IN THE ADVENTURE OF PINOCCHIO
}

\author{
Irma Ulfia Farahani, Wahju Kusumajanti, \\ Zulidyana Dwi Rusnalasari*
}

English Department, Faculty of Art and Humanities Islamic State

University of Sunan Ampel Surabaya, Indonesia

E-mail: zulidyana@unesa.ac.id

\begin{abstract}
This study attempts to analyze a fairy tale novel entitled "The Adventure of Pinocchio", which talks about the story of the irrepressible marionette who longed to become a real boy. This study focuses on revealing the categories of moral value and describing the building children's character implied in this novel. To analyze this novel, the researcher uses two principles theory to find out the objectives of the studies. There are moral values argued by Linda \& Eyre and the theory of children's character building based on Lewis. The method of this study is qualitative research, which means it does not need statistical procedure to analyze the material. This study merely uses "The Adventure of Pinocchio," a novel by Carlo Collodi, translated into English version by Carol Della Chiesa as the primary data source. At the same time, the secondary data sources are taken from other literary books and related references to support and complete the primary data. As a result, the researcher finds that some elements of moral values such as love and affection, sensitivity and not-selfish, bravery, self-discipline, and moderation occurred in the content of the novel. Meanwhile, building children's character can be implied through "The Adventure of Pinocchio's" fairy tale: honesty, responsible, regard, respect, and compassionated.
\end{abstract}

Keywords: Fairy Tale, Moral Value, Building Children Character.

\section{INTRODUCTION}

The popular story like Pinocchio has been famous for decades, and it sometimes raises several interpretations about the values within them. As we are familiar with this story, Pinocchio's character is considered as a boy made of wood and a clueless mind; with his adventure, he is dealing with lies that make him a human if he can avoid lies and be honest. Values about honesty, fatherhood and many other characters are really interesting to study further. In A Glossary of Literary Terms, Abrams states that novel involves fiction. It deals with one of the literary works with a great storyline and is made by the 
author (Abrams, 1999, p. 190). Also, the readers would pay attention to the aspects that build a novel, for instance, the intrinsic elements. Intrinsic elements deal with theme, character and characterization, setting, plot, point of view, and moral value, which are developed literary work inside (Austin \& Wellek, 1956, p. 73). Forster defines that over 50.000 words could extend in learning more about fiction in prose exactly novel that brings the moral value as the advantage within it (E.M. Forster, 2002, p. 8). Children are the primary source of judging and constructing values. Their frequency of moral thinking will increase as they read children's literature. Their appreciation for the imagery in children's literature will fuel their moral education and help them develop a strong moral personality (Miao-miao, 2006).

Furthermore, moral value stands with human behavior about the good and bad insight of view of life. It is such as the traits and actions of the character in so far they contribute to getting happiness (Ingpen, 2014, p. 47). In addition, according to Susana moral value likes a clue that the author deliberately wants to convey about various life issues such as behavior and manners (Susana, 2018, p. 287). Children's literature is a kind of literature and source, along with children's sight as the principal observer (Tarigan, 1995, p. 5). Despite children's literature learning many lessons, children ought to choose the best literary genre appropriate for their ages. Children's literature written for children has the feature of bearing morals; it helps develop children's moral thinking through spiritual dialogue between adults and children, and it teaches children to take on roles (Miao-miao, 2006). Hence, in this study, the genre of children's literature chosen is fairy tale which belongs to story about transformation, from childhood to be adulthood, from innocence to be experienced, and to this aim quest and blameless heroes are an essential element that might be consisted of all the fairy tales (Norton, 1987, p. 203).

In 1881, since The Adventure of Pinocchio initially published in the Italian Juvenile magazine Giornale Dei Bambini, La Adventure di Pinocchio: La Storia di un burattino soon had many followers and emerged as the most iconic of literary children all of the time (Ingpen, 2014, pp. 6-7). This story is originally written by Carlo Lorenzini, which known as the pen name "Carlo Collodi." He is the earliest Italian novel. For 130 years, children have delighted in The Adventure of Pinocchio fairy tales (Ingpen, 2014, p. 207). Besides, it has adapted to over 260 languages worldwide. It has also inspired a hundred new editions, merchandising, stage plays, and movies such as Walt Disney animated feature in 1940. (Gasparini, 2018, p. 117). Thus, The Adventure of Pinocchio's fairy tales English translation by Carol Della Chiesa is picked out as the objective of this study.

Numerous benefits can be derived from studying The Adventure of Pinocchio novel, particularly in the children's literary world and among specialized readers, both theoretically and practically: Theoretically, this study seeks to bolster the assumption regarding moral ideals contained in fairy tales, which are utilized to shape children's personalities. It influenced both literature and real life. Additionally, this study aims to bolster the theoretical foundations of literary studies, particularly those pertaining to the moral value as defined by Linda \& Eyre's theory and Lewis' method to developing children's character. Additionally, this study can be used as a 
supplement to future study in terms of learning and grasping how to study under the novel's moral values. Practically, by evaluating the Pinocchio novel, the writer can carry out defined objectives appropriately; it will also provide insight into the moral values depicted in this novel and what they mean in daily life. Generally, individuals are aware of the lesson of the prohibition of lying. Nonetheless, it is more. Additionally, teachers and parents can utilize these Italian classic fairy tales as examples of educational media to demonstrate what should be done by students and children when it comes to character development.

Some studies about The Adventure of Pinocchio novel by Indonesian scholars were found. First, the thesis which was conducted by Indah Junita. She studied the psychological transformations that happen to Pinocchio and find out that physical transformation happens to Pinocchio due to his behavior. Second, study was conducted by Maria which analyzes unconditional love through the two characters in the novel.

The most significant distinction between this article and those studies precede, is the author's determination to analyze moral value elements using the Linda and Eyre technique, as each work of literature contains moral value and children's literature is inextricably linked to psychology (Endraswara, 2016, p. 243). Additionally, by recognizing each of the novel's characters. The study intends to demonstrate how Lewis' theory applies to the development of children's characters.

\section{LITERATURE REVIEW}

The most effective strategy to minimize negative impacts is for individuals to pay attention to moral education, particularly for children while reading a novel. Thus, in this globalization period, it is important to recognize that morality does not only exist in classroom discussions but also in literature books such as novels that convey its messages - in a nutshell, morality is concerned with both good and bad deeds in human existence. Primarily, what is true is assessed morally. Meanwhile, immoral or amoral behavior is regarded as terrible (Hurlock, 1987, p. 67).

Etymologically, moral comes from Latin mos (Moris), which means tradition and habit (Hurlock, 1987, p. 89). Piaget (in Turiel, 2002, p. 1) assumes that moral is perspective development related to the construction of cooperation, justice, and equality. On the other hand, values consider the great worth and the important standard principles in life (seetha, 2018, p. 71). Rosenstand claims that generally the word "value" indicates moral value, assessment of human's behavior based on whether it is by specific rules or not (2006, p. 9). Because moral value is derived from comprehending God and the human value of life, it serves as a direction for human creativity and knowledge.

Linda and Eyre (1997, p. 3) suggested two types of values: values of being and values of giving. The value of being is the value that existed in human beings in behavior evolving and how the way a person treats others. It comprises of honesty, bravery, peace ability, purity and pureness, confident and potential, self-discipline, and moderation. Meanwhile, the value of giving deals with the values that tend to be operated or sustained, which would be deserved as giving (1997, p. 81). It consists of some kinds of values such as; 
love and affection, sensitive and not-selfish, respect loyalty and trustworthy, fair and humanist, kind and friendly. Everyone knows what a person does is the representation of their personality. Hence, everyone might be recognized whether a person reflects the good character or its opposite (Lexmend and Reeves, 2001, p. 11). There are six categorizing of positive character that was declared by (Lewis, 2004, p. 5) for instance; honesty, responsible, establishing justness and fair, regard and respect, compassionate.

\section{METHOD}

This study was conducted by using descriptive qualitative design which does not intend to find new theory but to find a new evidence to prove the theory. In this case, the researcher merely uses the novel The Adventure of Pinocchio that has been translated into English by Carol Della Chiesa as the primary data source. Beside that, the writer uses other sources outside of the novel that are closed to the subject and it can support the primary data, such as theory books, text book, other thesis or journal and internet source to improve the knowledge. In the data analysis, the researcher used some steps to analyze the data. First, the researcher is reading and understanding the entire story of The Adventure of Pinocchio. Second, selecting and collecting the data in form of narration and conversation from the novel related to the problem. Third, classifying the categorized data based on the objective the study. Fourth, analyzing the data one by one and then presenting the conclusion of the analysis result.

\section{FINDINGS AND DISCUSSIONS}

Moral values convey a message through guidance. It is portrayed by the character who acts in a positive or negative manner (Nasir, Samad, Jannah, \& Sharudin, 2019). The concept of good and evil is evaluated through the lens of kindness to effect change to become a better person in human existence. Berterns (2002) asserts that moral standards concern an individual's behaviors as a human being. Thus, moral standards encompass a grasp of what constitutes good and harmful human behavior in light of the social norms in place. Certain objects have a subjective notion of what is good and evil, as the studies found several categories found from the novel.

To avoid irrelevant issues, the author restricts themselves to Carlo Collodi's The Adventure of Pinocchio novel, illustrated by Robert Ingpen. The scope then narrows to identifying the internal element that corresponds to the moral values categories depicted in the plot. In terms of the ideas adopted, the author makes a distinction between moral ideals based on Linda and Eyre. Additionally, the author uses Lewis's technique to illustrate the moral ideals that are present as a part of children's character development.

\section{The categories of moral values that the author tries to convey in The Adventure of Pinocchio}

After the researcher understood and analyzed The Adventure of The Pinocchio, the researcher found some moral values in these fairy tales based on Linda \& Eyre's categorizing. 


\section{Love and Affection}

Since love and affection deals with the comfortable feeling toward someone which could be called home then never have in the entire life (Linda \& Richard, 1997, p. 124). Hence, Love and affection belong to moral values.

At first, he was very angry, but on seeing Pinocchio on stretched out on the floor and really without feet, he felt very sad and sorrowful. Picking him up from the floor, he fondled and caressed him, talking to him while the tears ran down his cheeks:

"My little Pinocchio, my dear little Pinocchio! How did you burn your feet?" (Chiesa, 1926, p. 38)

It happened when Pinocchio cried out loud to tell his condition without a pair of feet. Begin with Geppetto recognized that was just pranked, but when Geppetto climbed up in his home's side, he saw Pinocchio full of tears. He lost his anger and felt sorrow. He picked Pinocchio up and caressed him. Those are proof of Geppetto's affection.

\section{Sensitive and Not Selfish}

Considering moral values, sensitivity and not selfishness could be defined as a person's personality traits who had tendency displaying swiftly to appreciate other's feelings (Linda, 1997, p. 156). The following datum below is example of sensitive and not selfish moral values involved.

Think about how poor Harlequin felt! He was so scared that his legs doubled up under him and he fell to the floor. Pinocchio, at that heartbreaking sight, threw himself at the feet of Fire Eater and, weeping bitterly, asked in a pitiful voice which could scarcely be heard:

"Have pity, I beg of you, signore!"

"There are no signori here!"

"Have pity, kind sir!"

"There are no sirs here!"

"Have pity your Excellency!" (Chiesa, 1926, p. 55)

The manner had by the major character, Pinocchio depicted the moral values of sensitive and not selfish. It could be shown from the conversations above. As long Pinocchio as the marionette. Even if he had a naughty side, but he also had soft-heart like a human being. He felt pity seeing his friend, Harlequin frightened. Thus, Pinocchio sacrificed himself to save Harlequin. In these cases, Pinocchio threw himself under The Fire Eater feet to be the wood of the flames.

\section{Bravery}

Dare to take difficult risk to pass the life's task, or have the courage to do something uncredible troubled in the right way as the best option for the long term (Linda \& Richard, 1997, p. 17). All of these statements refer to the definition of bravery. In this term, bravery as moral values could be seen in the following below;

Pinocchio, although alone, defended himself bravely. With those two wooden feet of his, he worked so fast that his opponents kept at a respectful distance. Wherever they 
landed, they left their painful mark, and the boys could only

run away and howl. (Chiesa, 1926, p. 133)

The narratives above explain certain chronology, it was about the bravery of Pinocchio. Even though he was alone and fought seven fellows. Nonetheless, Pinocchio tended to keep his respectful distance with worked rapidly. In this way, unfortunately, wherever the boys landed, they left a painful mark on Pinocchio's wooden body.

\section{Self-Discipline and Moderation}

The expert believed that self-discipline and moderation deal with the self-practice to obey the rules and used the punishment to correct the fault. Lay it on the line, the Only datum which found as moral values of selfdiscipline and moderation could be shown in the quotation beneath.

From that day on, for more than five months, Pinocchio got

up every morning just as dawn was breaking and went to the farm to draw water. And every day he was given a glass of warm milk for his poor old father, who grew stronger and better day by day. But he was not satisfied with this. He learned to make baskets of reeds and sold them. With the money he received, he and his father were able to keep from starving. (Chiesa, 1926, p. 202)

As the protagonist character, Pinocchio carried on a huge role. After he realized all of his mistakes and remembered his dream about being the real boy, he changed his life better than before. In this case, the psychological manner had by Pinocchio indicated as the moral value of self-discipline and moderation. Pinocchio started work as hard as much to get closer with his aims. Day by day, Pinocchio waked up in the early morning and did something useful. He also did all of those things to make Geppetto happy.

After analyzing all of those data based on Linda and Eyre's theory of moral values. The writer determined that the moral values that the author tries to convey in this The Adventure of Pinocchio novel are love and affection, sensitive and not-selfish, bravery, self-discipline, and moderation.

\section{The moral values of The Adventure of Pinocchio that presented as the children's character building}

This subchapter tends to present what children's character building implied in The Adventure of Pinocchio novel. In this case, the researcher uses the main character (Pinocchio) as the representation of children. Thus, the researcher discusses five categorizing of children's character building one by one based on Lewis theory.

\section{Honesty}

Telling the truth is an obligation that everyone should do this type of good attitude. There is no exception; children also ought to behave and say something based on the real event. In this occasion, Pinocchio can build his character to be better as long as he learns what is forbidden and allowed to do.

Crying as if his heart would break, the Marionette mourned for hours over the length of his nose. No matter how he tried, it would not go through the door. The Fairy showed no pity toward him, as she was trying to teach him a good lesson so that he would stop telling lies, the worst habit 
any boy may acquire. But when she saw him, pale with fright and with his eyes half out of his head from terror, she began to feel sorry for him and clapped her hands together. A thousand woodpeckers flew in through the window and settled themselves on Pinocchio's nose. They pecked and pecked so hard at that enormous nose that in a few moments, it was the same size as before (Chiesa, 1926, p. 90).

The statement above is an example of the moral values that could be gained as the children's character building. A consequence who told lies, Pinocchio's nose became longer and longer. Then Pinocchio could not move in many places. In these cases, The Fairy tried to teach him about how important telling the truth and avoiding lies is. It shows the worst consequence as long as people are not honest.

\section{Responsible}

As the children's character building, responsible refers to human awareness of all intentional or unintentional behavior and actions. Responsible for The Adventure of Pinocchio novel reflected through selfdiscipline, moderation, and bravery, shown in the following data. In this case, self-discipline and moderation deal with a sense of obedience to the requested values as individual responsibility. Besides, bravery stands with someone who has a strong heart and great confidence to fight the dangers, difficulties, and so on.

From that day on, for more than five months, Pinocchio got up every morning just as dawn was breaking and went to the farm to draw water. And every day he was given a glass of warm milk for his poor old father, who grew stronger and better day by day. But he was not satisfied with this. He learned to make baskets of reeds and sold them. With the money he received, he and his father were able to keep from starving. (Chiesa, 1926, p. 202)

Specifically, the narrative above showed that Pinocchio was brave to take the risk of changing his life from the difficulties to be better. It caused Pinocchio to have a burden to take care of his only lovely father best. To achieve its aim, he determined to be disciplined by working hard every day and learning essential things to improve his life's quality.

\section{Regard and Respect}

In The Adventure of Pinocchio, respect is revealed to Pinocchio when he meets and talks to The Talking Cricket. As the representation of the children, Pinocchio in this fairy tale is illustrated as a stubborn and naughty marionette. Then when Talking Cricket gave him wise advice, he won't hear it. It could be seen in the following dialogue below;

"Oh, my dear Cricket," said Pinocchio, bowing politely.

"Oh, now you call me your dear Cricket, but do you remember when you threw your hammer at me to kill me?" "You are right, dear Cricket. Throw a hammer at me now. I deserve it! But spare my poor old father."

"I am going to spare both the father and the son. I have only wanted to remind you of the trick you long ago played 
upon me, to teach you that in this world of ours we must be kind and courteous to others if we want to find kindness and courtesy in our days of trouble." (Chiesa, 1926, pp. 198-199)

At the end of this story, Pinocchio realized how rude he was. Thus he told all of his faults and feel regretful. In this case, Pinocchio wanted The Talking Cricket to throw the hummer to him as he has done to The Talking Cricket. The Talking Cricket won't do revenge because all of his wanted is to remind Pinocchio how to respect others.

\section{Compassionate}

Since compassion is the further children's character building, human emotions arise due to the suffering of others. Hence, these children's character could be built through two moral values. First, love and affection refer to the feeling that appears in the sincere heart to accept, love, and give happiness to others. Second, sensitive and not selfish, which means do care towards others. As reflected in some data such as;

At first, he was very angry, but on seeing Pinocchio on stretched out on the floor and really without feet, he felt very sad and sorrowful. Picking him up from the floor, he fondled and caressed him, talking to him while the tears ran down his cheeks:

"My little Pinocchio, my dear little Pinocchio! How did you burn your feet?" (Chiesa, 1926, p. 38)

Through the main character of Pinocchio and Geppetto, the narrative above showed that Pinocchio's dad has endlessly loved to his son. Despite he was mad cause Pinocchio was very naughty but when he saw Pinocchio cried out loud to tell his condition without a pair of feet. He lost his anger and felt sorrow. He picked Pinocchio up and caressed him. Therefore, such evidence that these two kinds of moral values could build children's character to be compassionate.

After analyzing all of those data based on Lewis theory of Children's character building to answer second statement problem, The writer determined that The Adventure of Pinocchio fairy tale implied four kinds of children's character building. Such as; honesty, responsible, regard, and respect, compassion.

To prevent the non-relevant problems, the writer makes a limitation to Carlo Collodi's The Adventure of Pinocchio novel which Robert Ingpen has illustrated. The scope then focuses on finding the internal element that stands with the moral values depicted in the storyline.

This study was only about one from many of classic stories, more further study in other classic will enrich the literacy world. The study of classic works and relate them with the analysis of the current condition. When we are pretty sure about the moral lesson inside particular classic works, we will feel sure to deliver these stories to our next generation.

\section{CONCLUSION}

The Adventure of Pinocchio is Italian classic fairy tale written by Carlo Collodi. As children literary work, this novel ought to imply moral value. In this case, after conducting this study, the writer revealed several moral 
values. They are respect, love and affection, sensitive and not selfish, honesty, bravery, self-discipline and moderation. Moreover, these moral values also could be developed children's character building as like; Honesty as moral values can build Honesty characters; Self-Discipline and Moderation and Bravery as moral values can build Responsible characters; Respect can establish Regard and Respect characters; Love and Affection and Sensitive and Not-Selfish as moral value can build children to be Compassonate.

\section{REFERENCES}

Abrams, M. H. A. (1999). Glossary of Literary Terms seven edition. Cornell University Heinle \& Heinle Thomson Learning.

Austin, W., \& Wellek, R. (1956). Theory of Literature. New York: Harcourt, Brace \& World.

Bertens, K. (2002). Etika. Jakarta: Gramedia Pustaka Utama.

Chiesa, C. D. (1926). The Adventure of Pinochio.

E.M. Forster. (2002). The aspect of the novel. New York: Rosetta Books LLC.

Endraswara, S. (2016). Metodologi Penelitian Ekologi Sastra-Konsep, Langkah, dan Penerapan. Yogyakarta: Caps.

Hurlock, E. (1987). Moral Development. Mc Graw: Hill Book Company.

Ingpen, R. (2014). The Adventure of Pinocchio. UK: Templar Publishing.

Lewis, B. (2004). Karakter Building untuk Remaja. Batam: Kharisma Publishing Group.

Linda, E., \& Richard. (1997). Teaching Your Children Value. New York: Fireside Rockfeller Center.

Miao-miao, C. (2006). The Value of Children Literature to the Development of Children's Morality. Journal of Hunan University of Science and Engineering. https://doi.org/null

Nasir, C., Samad, I. A., Jannah, T. M., \& Sharudin, E. S. (2019). AN ANALYSIS OF MORAL VALUES IN THE MOVIE “COCO.” Null. https://doi.org/null

seetha, K. (2018). Need For Value-Based Spiritual Education In Schools. P.71. Retrieved from https://www.sciencedirect.com/journal/...journal...educational.pdf

Susana, E. (2018). Moral Value in Charlotte Bronte's Novel Jane Eyre. KnE Social Sciences, 3(4), 287. https://doi.org/10.18502/kss.v3i4.1940

Tarigan, H. G. (1995). Dasar-dasar Psikosastra. Bandung: Angkasa.

Turiel, E. (2002). The Culture of Morality (Social Development, Context, and Conflict). USA: Cambridge University Press. 